\title{
Comparison of Split Windows Algorithm and Planck Methods for Surface Temperature Estimation Based on Remote Sensing Data in Semarang
}

\author{
Siti Zahrotunisa $^{1^{*}(\mathbb{D})}$, Projo Danoedoro2 ${ }^{2}$, Sanjiwana Arjasakusuma ${ }^{3}$ (D) \\ ${ }^{1}$ Magister of Remote Sensing, Faculty of Geography, Universitas Gadjah Mada, Yogyakarta, Indonesia \\ 2,3Department of Remote Sensing, Faculty of Geography, Universitas Gadjah Mada, Yogyakarta, Indonesia
}

\section{ARTICLE INFO}

Article History:

Received: April 24, 2021

Revision: October 29, 2021

Accepted: October 31, 2021

Keywords:

Surface Temperature

Split Windows Algorithm

Planck

Corresponding Author

E-mail:

siti.zahrotunisa95@gmail.com

\begin{abstract}
Surface temperature is one of the parameters in land-surface physical processes and is applied to global warming, climate change, and cycle hydrology. Two thermal bands in Landsat 8 imagery can be used as input for surface temperature extraction using the Split Windows Algorithm (SWA) and Planck method. This study aims to compare surface temperature estimates using the SWA and Planck methods and determine the surface temperature distribution based on the condition of land cover and its changes. The remote sensing data used are Landsat- 8 OLI/TIRS Aqua MODIS images on August 27, 2013, and October 1,2020 . The results showed that Landsat 8 could obtain land cover information with an accuracy of $90 \%$ in 2013 and $91 \%$ in 2020. Planck surface temperature in 2013 was $1-3^{\circ} \mathrm{C}$ higher than SWA, while in 2020 , Planck was $0.001-0.05^{\circ} \mathrm{C}$ lower than SWA but had similar distribution and pattern. The vegetation in the study area's central and south sides has a lower surface temperature than the built-up area on the north side. Land cover changes from non-built up to build-up area cause surface temperatures to increase. Each land cover has a different emissivity value and affects the surface temperature value, i.e., the lower the emissivity, the higher the surface temperature. The emissivity with surface temperature has a pearson correlation value $\geq-0.8^{* *}$.
\end{abstract}

\section{INTRODUCTION}

Land surface temperature reflects the amount of radiation emitted from the surface and sub-surface of the earth and the exchange of energy between the earth's surface and atmosphere (Weng et al., 2019). Land surface temperature is one of the critical parameters used to analyze global warming, climate change, and the hydrological cycle (Li et al., 2013; Ferreira et al., 2016; Jatmiko, 2016). Multitemporal analysis of surface temperature can predict fish catchment areas in the sea (Nurman, 2010). The surface temperature can be estimated from radiance measurements by meteorological stations, but this method does not generally allow large-scale monitoring since it is a point-based measurement (Hale et al., 2011). Semarang city and its surroundings have a variety of land cover that can provide a spatially varied range of surface temperature values.

Due to the aggravation of the heat island effect, current research on LST is mainly focused on urban areas. Analyzing surface temperatures for various land uses optimizes the distribution of green space to reduce the heat island effect $(X$. Li et al., 2013). The urban area is warmer than the suburban area because the metropolitan area is mainly covered by built-up areas (compact low-rise buildings, large low-rise buildings, roads, and paved) (Nurwanda \& Honjo, 2018). Land cover area and its changes affect surface temperature (Abas et al., 2017; Sasky et al., 2017). Knowing the relationship 
between land cover and surface temperature helps analyze the relationship between changes that occur over a specific time (Bokaie et al., 2016).

The remote sensing method is more effective in estimating land surface at large temporal and spatial scales than traditional measurement (Chen et al., 2017). Various land surface products produced from satellite data have been widely used in the urban ecological environment, natural disasters, and water management (Meng et al., 2019). Thermal remote sensing captures the radiation emitted from the ground primarily to estimate the surface temperature (Sekertekin \& Bonafoni, 2020). Surface temperature values can be obtained spatially using Landsat 8 . Two thermal bands in Landsat 8 imagery, bands 10 and 11, can be used as input for surface temperature processing. Another benefit of Landsat 8 is that images are available for free and have a temporal resolution of 16 days, allowing for multitemporal analysis (Department of the Interior U.S. Geological Survey, 2016).

Split Window Algorithm (SWA) and Planck can extract surface temperature. SWA uses two thermal bands with different absorption characteristics to produce atmospheric attenuation information on thermal radiation (Rozenstein et al., 2014). SWA for atmospheric correction can minimize errors in surface temperature retrieval (Rozenstein et al., 2014). SWA is commonly employed because it does not require high precision atmospheric profiles (Chen et al., 2017; Wang et al., 2019). Emissivity and atmospheric transmission are two other SWA inputs. Emissivity can be calculated based on land cover (Jensen, 2014) and atmospheric transmission obtained based on the correlation with water vapor content. The water vapor content was calculated using a near-infrared band from the Aqua MODIS.

The Planck method is used to compute the thermal radiation intensity, or the amount of thermal electromagnetic radiation emitted by a blackbody under thermal equilibrium conditions at a known temperature (Ndossi \& Avdan, 2016). The surface temperature is obtained using the emissivity image by inverting the Planck equation. The Planck method uses Landsat 8 band ten because band 11 has experienced calibration instability since March 29, 2016 (Department of the Interior U.S. Geological Survey, 2016).

Many scholars have studied the method for surface temperature retrieval. Mono Windows Algorithm (MWA), SWA, and Single Channel (S.C.) can retrieve the surface temperature correctly (Wang et al., 2019). All three algorithms produce the same spatial variation of surface temperature, and the surface temperature of the urban area was significantly higher than the suburbs. In high temperature and humid regions, the SWA is recommended. All three algorithms can be used in the case of low temperature and water vapor content. The Planck function has the highest accuracy, SWA has medium accuracy, and SCA has the most insufficient accuracy (Ndossi \& Avdan, 2016). The SWA has the lowest observed RMSE $\left(1.6-2^{\circ} \mathrm{K}\right)$, S.C. has RMSE value (2.0$\left.2.3^{\circ} \mathrm{K}\right)$, and the radiative transfer equation (RTE) has the highest observed RMSE values (2.0-3.6 K) (García-Santos et al., 2018).

Surface temperature data from thermal infrared remote sensing data, often used for studying urban heat island effects (Azevedo et al., 2016; Nurwanda \& Honjo, 2018). The diversity of algorithms or methods for surface temperature estimation makes it difficult for scholars to choose the proper technique. The study results can be used as a reference to choose the appropriate method for surface temperature retrieval. This research aims to determine the comparison of surface temperature value using the SWA and Planck methods and to determine the surface temperature based on land cover conditions and changes.

\section{RESEARCH METHODS}

Generally, this research is divided into three phases: pre-field survey, field survey, and post-field survey. The pre-field survey 
consists of preparing the data used in the study and data processing carried out to obtain research results. The field survey is to get data to test the remote sensing data extraction results' accuracy in the pre-field survey. The post field survey includes all activities to complete the data processing and analysis

The research was conducted in Semarang city and its surroundings, urban and rural areas (Figure 1). The site is located at $110^{\circ} 17^{\prime} 49^{\prime \prime} \mathrm{E}-110^{\circ} 28^{\prime} 58^{\prime \prime} \mathrm{E}$ and $6^{\circ} 56^{\prime} 6^{\prime}$ 'S - $7^{\circ} 11^{\prime} 46^{\prime \prime} S$. The area has varieties of land cover, so this can describe the distribution of surface temperature on the different land cover. The research area also covered homogeneous areas such as urban areas with dominant built-up areas, rural areas with dominant vegetation, and transition areas to analyze the surface temperature in these areas.

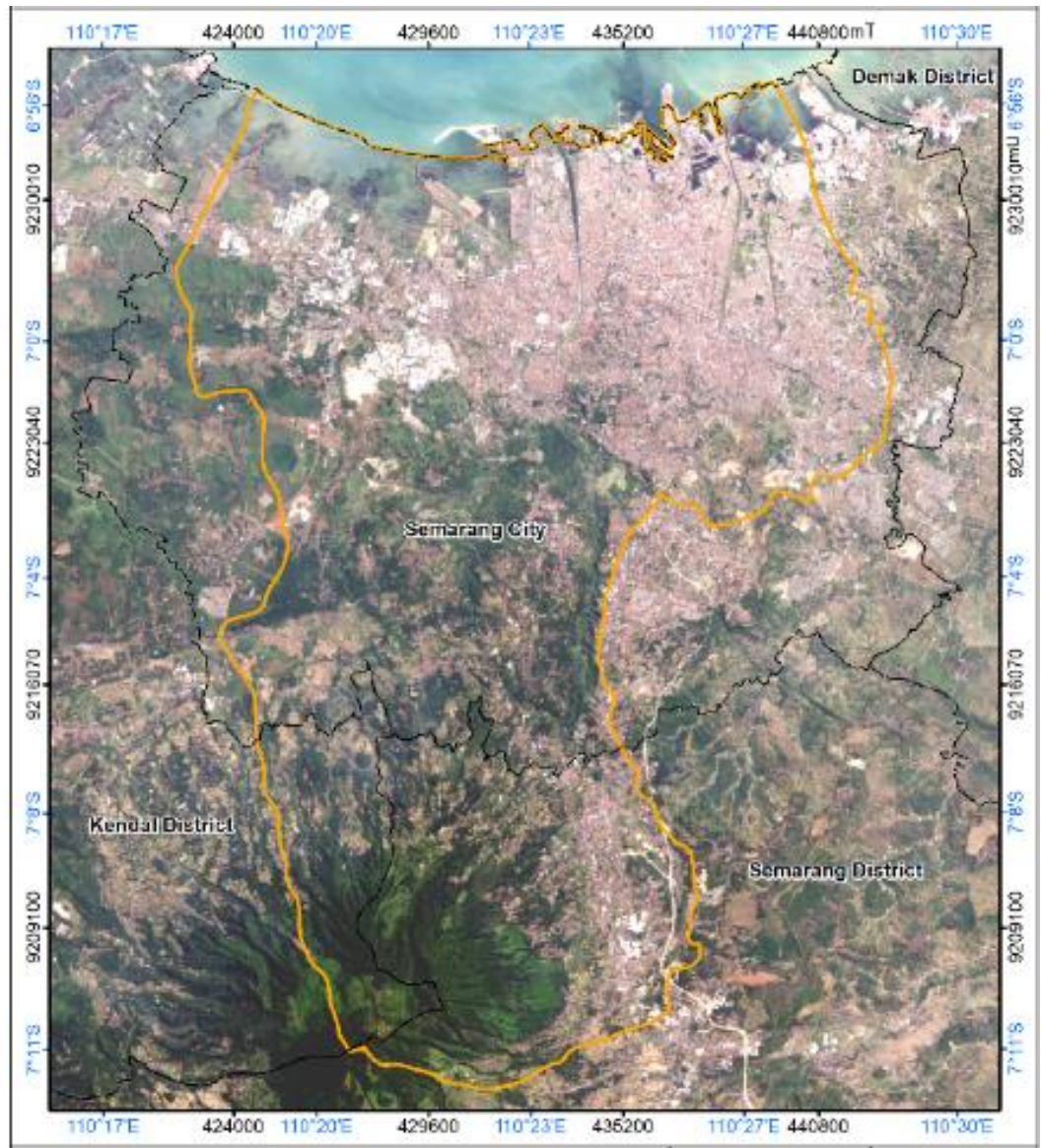

Figure 1. The location of the research area

The remote sensing data used were Landsat-8 OLI / TIRS and modified Aqua MODIS images on August 27, 2013, and October 1, 2020. Landsat-8 OLI was used to classify land cover and emissivity, Landsat 8 TIRS, and Aqua MODIS to obtain surface temperature.

The data processing phase consists of geometric correction, radiometric correction, multispectral classification, surface emissivity extraction, surface temperature extraction, and field sample identification.
Landsat 8 level 1T image is a globally corrected geometric image using DEM and GCP with a horizontal accuracy $\leqq$ of 12 meters (Dianovita \& Mahendra, 2014). Geometric corrections were carried out on the Aqua MODIS image due to a narrowing in a specific area, and the image position was reversed. The maximum likelihood was used to obtain land cover data. The classified land cover based on the value of the object's emissivity can be seen in 30 meters resolution (Table 1). 
Table 1. Emissivity based on land cover

\begin{tabular}{lc}
\hline \multicolumn{1}{c}{ Land cover } & Emissivity \\
\hline Closed canopy vegetation & 0,98 \\
Open canopy vegetation & 0,96 \\
Tile roof & 0,92 \\
Zinc & 0,90 \\
Concrete & 0,90 \\
Wet soil & 0,95 \\
Dry soil & 0,92 \\
Water bodies & 0,98 \\
Tar & 0,95 \\
\hline
\end{tabular}

Source: (Jensen, 2014).

Surface emissivity was obtained using the equation referred to in Table 1 . The estimation of the surface temperature using SWA refers to the equation from (Rozenstein et al., 2014) and Planck equation from (Tan et al., 2017). Stratified random sampling was used to determine samples based on land cover class. There were 100 point samples.

The field survey included checking the land cover sample points and interviewing residents to gather information about land cover changes. The resulting land cover classification was assessed its accuracy using the confusion matrix method (Congalton \&
Green, 2008) by comparing the classification results with field data. The higher the overall accuracy value, the more precise the land cover classification results are. Descriptive analysis was carried out on the land surface temperature extraction and land cover. Each land cover has an emissivity value as an input parameter to obtain surface temperature. Then, statistical analysis Pearson product-moment (Sugiyono, 2007) to determine the relation, direction, and emissivity influence surface temperature. Figure 2 shows the research flowchart.

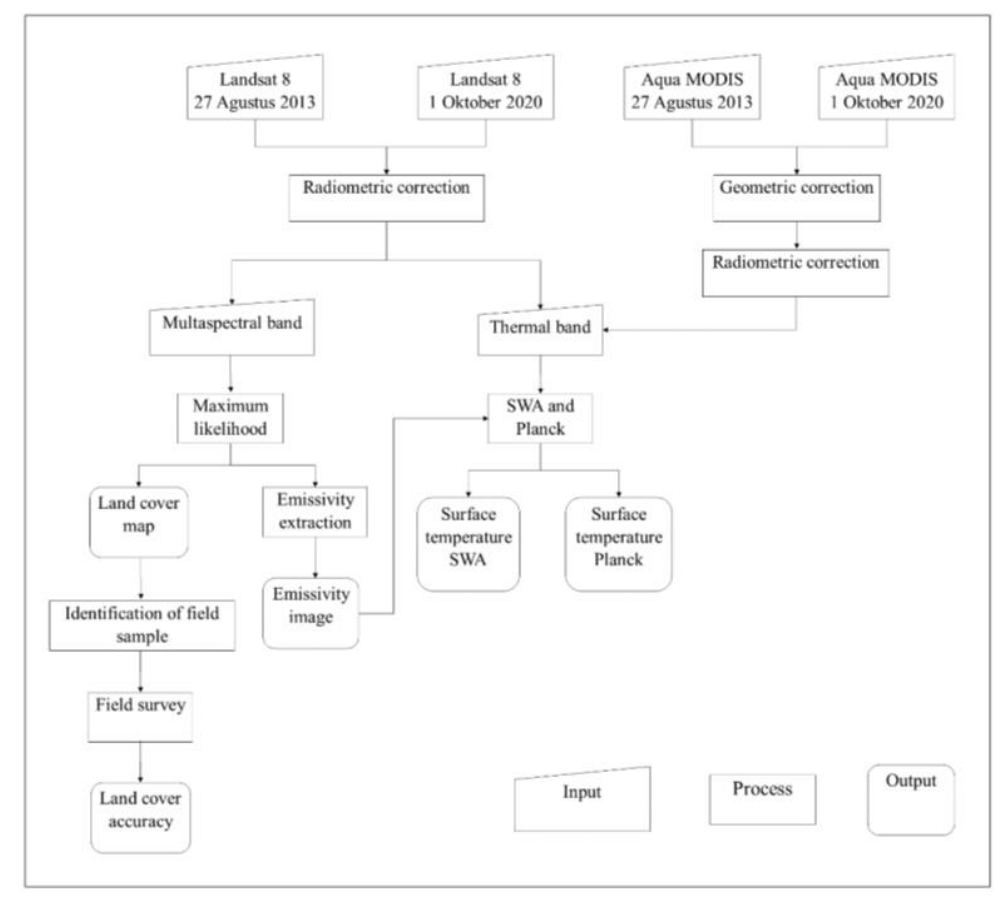

Figure 2. Research flowchart 


\section{RESULT AND DISCUSSION}

\section{Land Cover Change}

The land cover classification accuracy is influenced by the ability to identify objects and the Region of Interest (ROI) quality of land cover samples. The distribution and sample amount influence ROI quality. It can also be specified with separability value in land cover class, i.e., ranges between $0-2$. The higher the separability ROI value, the better the sample taken due to the different land cover levels. Classification results get separability value near on 2 , more than 1.5 .
The accuracy test is carried out by comparing the classification results with existing land cover, the results of interviews with residents(Sejati et al., 2020), and highresolution images (Putri \& Wicaksono, 2021). Land cover classification using maximum likelihood on Sentinel-2 has an overall accuracy of $95.6 \%$ (Indarto et al., 2020). This research used Landsat- 8 for land cover classification and produced accurate results, with an overall accuracy of $90 \%$ in 2013 and $91 \%$ in 2020. The result can be seen in Figure 3.
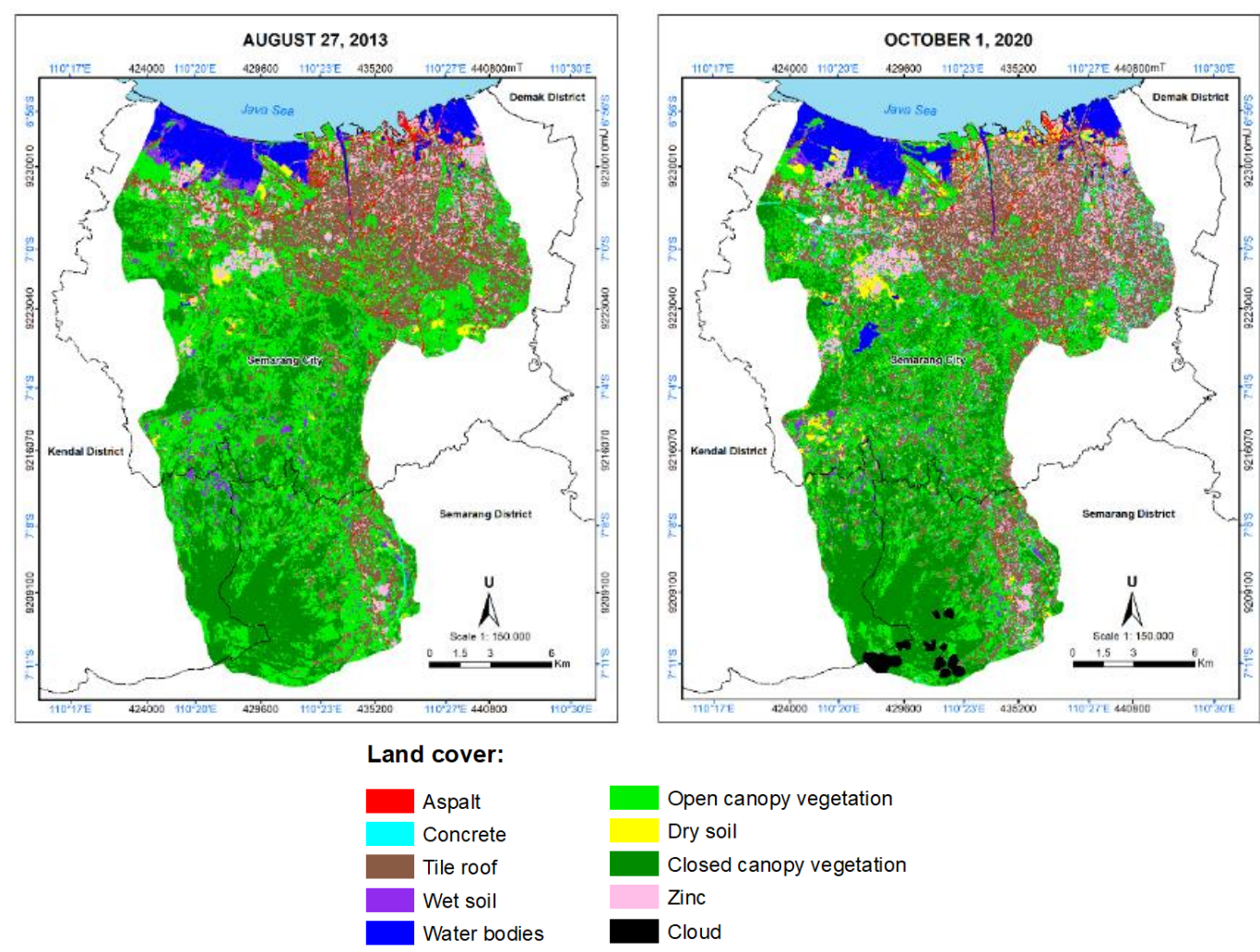

Figure 3. Land cover map of the research area 2013 and 2020

Figures 3 and 4 show the distribution of 9 land cover classes in 2013 and 2020. Built-up area is the dominant land cover, including zinc land cover, tile roofs, concrete in the north and east, water bodies in the north, open canopy, closed-canopy objects in the west and south. The built-up area does not go through a transformation, while the non-built-up area, i.e., vegetation in the south and west side, tends to change into a built-up area. The expansion of the built-up area in the study area is not very significant, but these changes occur larger. Land cover changes at the west side of Semarang city, i.e., settlement conversion and vegetation changes into a highway (Semarang-Batang), the increase of building in BSB residential land, the increase industrial buildings in Candi industrial area, and vegetation conversion into Jatibarang reservoir.

The resulting land cover changes were not always purely caused by changes in the field. Still, they can also be caused by differences in image acquisition time, considering that several land cover classes in the study area are strongly influenced by 
season. Dryland and open canopy (rice field) are controlled by planting time, so it is possible that the fields were not in the planting season during image acquisition. Vegetation near an existing built-up area tends to trigger the expansion of the built-up area. Based on the interviews with residents, the trend in recent years is a strong desire to settle in the central part of Semarang City and around Semarang Regency. This is triggered by the condition in the northern side of Semarang city is not conducive due to the hot temperature, air pollution from heavy vehicle roads, tidal flooding, and lack of green space.

\section{Comparison Surface Temperature}

Land cover maps are used to obtain emissivity images. Emissivity image used as an input for surface temperature extraction using SWA and Planck method. Figures 5 and 6 show the surface temperature from both approaches in the study area.

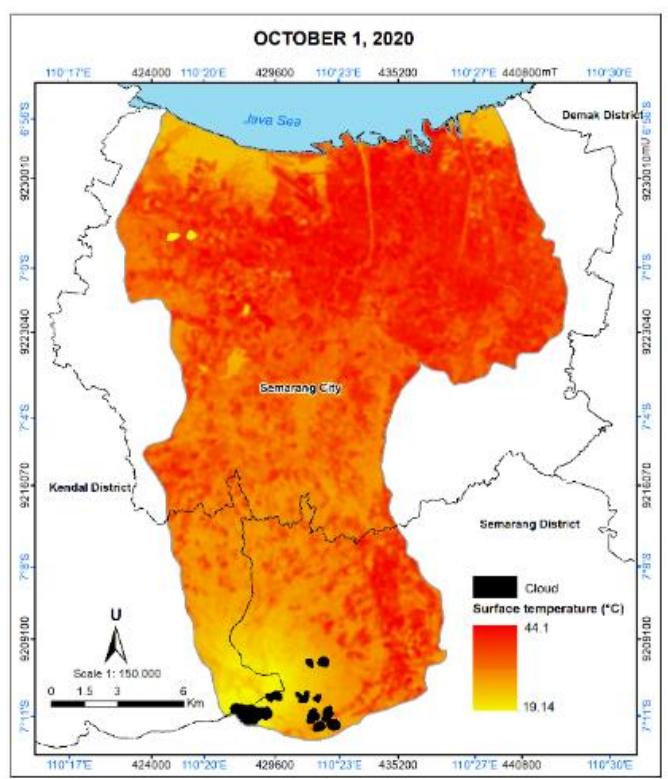

Figure 5. SWA method surface temperature of research area 2013 and 2020
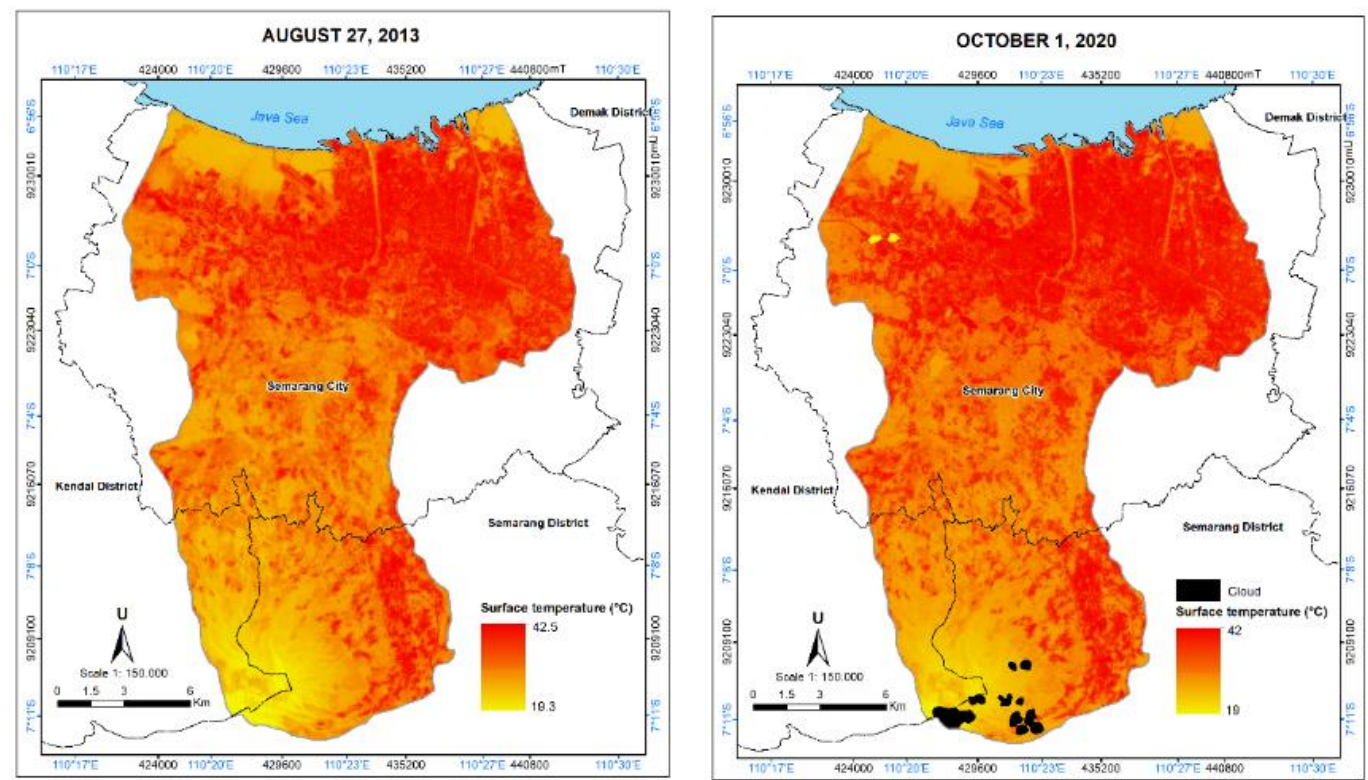

Figure 6. Planck method surface temperature of research area 2013 and 2020 
Figure 5 indicates the results of the SWA method in 2013 and 2020 have surface temperature values between $18-45^{\circ} \mathrm{C}$. Surface temperature from the Planck method is lower than SWA, i.e., at ranges 18 $-43^{\circ} \mathrm{C}$. Both ways generate different fields of temperature values but have similar distribution and patterns because the equations and input parameters are other. SWA uses two thermal bands that have different absorption characteristics, emissivity data, and atmospheric transmission, while planck uses one thermal band and emissivity data. High surface temperature in the north and east sides of Semarang City from 2013-2020. The increase in surface temperature occurred in the western side of Semarang City and the central to southern side due to the built-up area expansion. The south side of the study area, around Mt. Ungaran, has a low surface temperature and tends not to change since it is a conservation area. This shows that variations influence variations in surface temperature in topography or altitude, namely, the higher the length, the lower the surface temperature.

Figure 7 shows object zinc and concrete have high surface temperature while water bodies and closed canopy have a low surface temperature. The tile roof has a similar temperature with zinc and concrete. The tile roof is close to another built-up area such as zinc, concrete, tar that make the different objects radiate then affect its surface temperature value. Planck surface temperature in 2013 was $1-3^{\circ} \mathrm{C}$ higher than SWA, while in 2020 , Planck was $0.001-0.05^{\circ} \mathrm{C}$ lower than SWA.

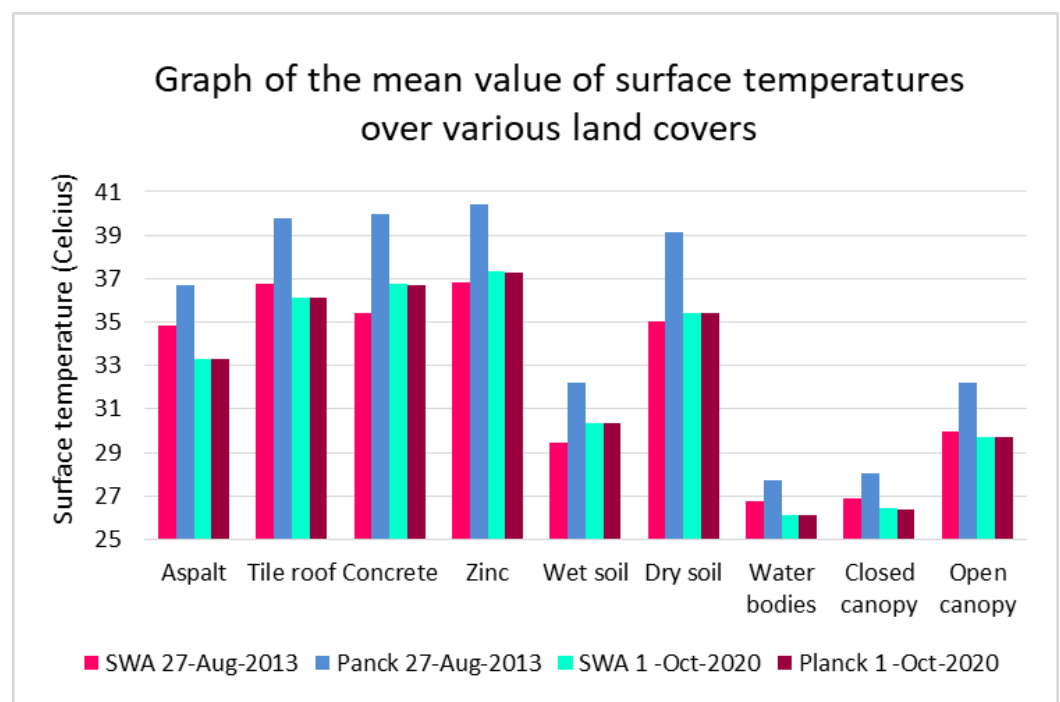

Figure 7. Graph of the mean value of surface temperatures over various land covers

The surface temperature is higher than the air temperature, and the higher the surface temperature, the higher the air temperature (Wiweka, 2014; Azevedo et al., 2016). The estimation results of the surface temperature of the SWA and Planck methods are higher than the air temperature, so the estimation results are correct based on the relationship (Table 2). SWA with air temperature has a more significant difference in value than Planck with air temperature. The error value of the SWA and Planck estimation results cannot be calculated because there are no surface temperature data from secondary reference or field measurement. The results of surface temperature extraction from remote sensing data are difficult to verify (Wang et al., 2019). 
Table 2. Surface temperature values obtained from SWA, Planck, and air temperature values at meteorological and climatological stations in Semarang

\begin{tabular}{lcc}
\hline & October 1, 2020 & August 27, 2013 \\
\hline Climatology Station Class I Semarang & 33 & 31 \\
(Air Temperature) & 35 & 38 \\
SWA & 33.46 & 36.8 \\
Planck & -2 & -7 \\
Climatology -SWA & -0.46 & -5.8 \\
Climatology -Planck & & \\
Meteorology Station Class II Ahmad & 33.6 & 27.7 \\
Yani & & \\
(Air Temperature) & 37 & 38.5 \\
SWA & 32 & 35.3 \\
Planck & -3.4 & -10.8 \\
A Yani-SWA & 1.6 & -7.6 \\
A Yani-Planck & & \\
Meteorology Station Class II Tanjung & 32.2 & 27.7 \\
Mas & & \\
(Air Temperature) & 35 & 41.2 \\
SWA & 33.4 & 36.6 \\
Planck & -2.8 & -13.5 \\
T Mas-SWA & -1.2 & -8.9 \\
T Mas-Planck & & \\
\hline
\end{tabular}

Table 3 shows that the vegetation objects in 2013 changed into concrete and zinc, increasing the surface temperature. The open canopy changed into a closed top, causing the surface temperature to decrease.
The water bodies changed into dry soil, causing the surface temperature to increase-the more vegetation and water, the lower the surface temperature.

Table 3. Examples of surface temperature values due to changes in land cover

\begin{tabular}{ccccc}
\hline Sample number & 1 & 11 & 73 & 105 \\
\hline Object 2013 & Water bodies & Open canopy & Closed canopy & Open canopy \\
Object 2020 & Dryland & Concrete & Zinc & Closed canopy \\
SWA 2013 & 28.88 & 35.19 & 32.16 & 32.73 \\
Planck 2013 & 28.85 & 35.32 & 32.37 & 32.9 \\
SWA 2020 & 36.5 & 38.69 & 38.32 & 26.61 \\
Planck 2020 & 36.5 & 38.6 & 38.3 & 26.6 \\
\hline
\end{tabular}

Pearson Product Moment Analysis

Both methods use the emissivity value of each land cover. Therefore, the
Pearson product-moment correlation is used to analyze the effect of emissivity on surface temperature (Table 4 and 5).

Table 4 . The results of the correlation between the Pearson product-moment of emissivity and surface temperature in 2013

\begin{tabular}{llcc}
\hline & & SWA 2013 & Planck 2013 \\
\hline \multirow{3}{*}{ Emissivity 2013 } & Pearson Correlation & $-0,8^{* *}$ & $-0,82^{* *}$ \\
& Sig. (2-tailed) & 0 & 0 \\
& $\mathrm{~N}$ & 100 & 100 \\
\hline
\end{tabular}


Table 5. The results of the correlation between the Pearson product-moment of emissivity and surface temperature in 2020

\begin{tabular}{llcc}
\hline & & SWA 2013 & Planck2020 \\
\hline \multirow{3}{*}{ Emissivity 2020 } & Pearson Correlation & $-0,88^{* *}$ & $-0,84^{* *}$ \\
& Sig. (2-tailed) & 0 & 0 \\
& $\mathrm{~N}$ & 100 & 100 \\
\hline
\end{tabular}

Tables 4 and 5 show emissivity with surface temperature has a robust correlation and negative and significant correlation. The strong and significant correlation can be seen from the correlation value $>0.8^{* *}$. Emissivity affects surface temperature $>64 \%$, and the rest are from other factors. The direction of the correlation is that the higher the emissivity, the lower the surface temperature. The lower the ability to absorb heat, the higher the emissivity value, and the higher the ability of the object to absorb heat, the lower the emissivity value. Table 1 and the surface temperature map show that the closed canopy and the water bodies have the highest emissivity value of 0.98 and a low surface temperature of $26-28^{\circ} \mathrm{C}$. Zinc and concrete have a low emissivity value of 0.9 and a high surface temperature of $35-40^{\circ} \mathrm{C}$.

\section{CONCLUSION}

Estimated Land surface temperature carried out using the SWA and Planck methods has a slight difference value of 2020 , while in 2013 , Planck was higher $1-3^{\circ} \mathrm{C}$ than SWA. Both approaches have similar distribution and pattern that urban area on the north side has a high surface temperature. In contrast, vegetation on the central and southern sides has a low surface temperature. It can be concluded that the use of two Landsat 8 thermal bands and the atmospheric transmission value of Aqua MODIS in the SWA method have more influence on the results of the estimated surface temperature in 2020.

The land cover change occurred in the north, west, and central to the south side of the study area from 2013-2020 - land cover changes from non-built to build-up area cause the surface temperatures to increase. Several land cover changes, i.e., industrial buildings, toll roads, and residential land. The more vegetation and water, the lower the surface temperature, and the more build-up area, the higher the surface temperature. The emissivity value of land cover with surface temperature value has a significant and robust correlation $\left(>0.8^{* *}\right)$. The higher the emissivity, the lower the surface temperature.

\section{ACKNOWLEDGMENT}

The author would like to thank LPDP, who has provided funding for this research.

\section{REFERENCE LIST}

Abas, N., Kalair, A. R., Khan, N., \& Kalair, A. R. (2017). Impact of Urbanization Growth on Land Surface Temperature using remote. Renewable and Sustainable Energy Reviews, 80(June), 990-1016.

http://dx.doi.org/10.1016/j.rser.2017 .04 .022

Azevedo, J. A., Chapman, L., \& Muller, C. L. (2016). Quantifying the daytime and night-time urban heat Island in Birmingham, UK: A comparison of satellite derived land surface temperature and high resolution air temperature observations. Remote Sensing, $8(2)$. https://doi.org/10.3390/rs8020153

Bokaie, M., Zarkesh, M. K., Arasteh, P. D., \& Hosseini, A. (2016). Assessment of Urban Heat Island based on the relationship between land surface temperature and Land Use/ Land Cover in Tehran. Sustainable Cities and Society, 23, 94-104. https://doi.org/10.1016/j.scs.2016.03. 009

Chen, Y., Duan, S. B., Ren, H., Labed, J., \& Li, Z. L. (2017). Algorithm development for land surface temperature retrieval: Application to Chinese Gaofen-5 data. Remote Sensing, 9(2). 
https://doi.org/10.3390/rs9020161

Congalton, R., \& Green, K. (2008). Assessing the Accuracy of Remotely Sensed Data: Principles and Practices (Second Edition).

Department of the Interior U.S. Geological Survey. (2016). Landsat 8 Data Users Handbook. Nasa, 8(June), 97. https://landsat.usgs.gov/documents /Landsat8DataUsersHandbook.pdf

Dianovita, \& Mahendra, R. (2014). KAJIAN KETELITIAN GEOMETRI CITRA LANDSAT 8 LEVEL 1T. Seminar Nasional Penginderaan Jauh 2014, 254260.

Ferreira, E., Mannaerts, C. M., Dantas, A. A., \& Maathuis, B. H. (2016). Surface energy balance system (SEBS) and satellite data for monitoring water consumption of irrigated sugarcane. Engenharia Agricola, 36(6), 1176-1185. https://doi.org/10.1590/1809-4430-

Eng.Agric.v36n6p1176-1185/2016

García-Santos, V., Cuxart, J., MartínezVillagrasa, D., Jiménez, M. A., \& Simó, G. (2018). Comparison of three methods for estimating land surface temperature from Landsat 8-TIRS Sensor data. Remote Sensing, 10(9), 113.

https://doi.org/10.3390/rs10091450

Hale, R. C., Gallo, K. P., Tarpley, D., \& Yu, Y. (2011). Characterization of variability at in situ locations for calibration/validation of satellitederived land surface temperature data. Remote Sensing Letters, 2(1), 4150 .

https://doi.org/10.1080/01431161.20 10.490569

Indarto, I., Mandala, M., Febrian Arifin, F., \& Lukman Hakim, F. (2020). Aplikasi Citra Sentinel-2 Untuk Pemetaan Tutupan Dan Peruntukan Lahan Pada Tingkat Desa. Jurnal Geografi, 12(02), 189.

https:// doi.org/10.24114/jg.v12i02.1 6970

Jatmiko, R. (2016). Penggunaan Citra Saluran Inframerah Termal untuk Studi Perubahan Liputan Lahan dan Suhu sebagai Indikator Perubahan Iklim
Perkotaan di Yogyakarta. Universitas Gadjah Mada.

Jensen, J. R. (2014). Remote Sensing of the Environtment An Earth Resource Perspective Second Edition. Pearson Education Limited.

Li, X., Zhou, W., \& Ouyang, Z. (2013). Relationship between land surface temperature and spatial pattern of greenspace: What are the effects of spatial resolution? Landscape and Urban Planning, 114(June), 1-8. https://doi.org/10.1016/j.landurbpla n.2013.02.005

Li, Z., Liu, X., Ma, T., Kejia, D., \& Zhou, Q. (2013). Retrieval of the surface evapotranspiration patterns in the alpine grassland - wetland ecosystem applying SEBAL model in the source region of the Yellow River, China. Ecological Modelling, 270, 64-75. https://doi.org/10.1016/j.ecolmodel. 2013.09.004

Meng, X., Cheng, J., Zhao, S., Liu, S., \& Yao, Y. (2019). Estimating land surface temperature from Landsat-8 data using the NOAA JPSS enterprise algorithm. Remote Sensing, 11(2), 1-18. https://doi.org/10.3390/rs11020155

Ndossi, M. I., \& Avdan, U. (2016). Inversion of land surface temperature (LST) using terra aster data: A comparison of three algorithms. Remote Sensing, 8(12), 1-19.

https://doi.org/10.3390/rs8120993

Nurman, A. (2010). Pemanfaatan Data Modis Untuk Mendeteksi Daerah Tangkapan Ikan Pantai Timur Dan Barat Sumatera Utara. Jurnal Geografi, 2(2), 17-30.

Nurwanda, A., \& Honjo, T. (2018). Remote sensing can analyze land use change and expansion of surface urban heat islands in Bogor city. ISPRS International Journal of Geo-Information, 7(5).

https://doi.org/10.3390/ijgi7050165

Putri, L. M., \& Wicaksono, P. (2021). Mapping Of Land Use Changes In The Core Zone Of Parangtritis Sand Dunes Using Obia Method 2015-2020. Jurnal 
Geografi, 13(1), 109-120. https://doi.org/10.24114/jg.v\%vi\%i. 21465

Rozenstein, O., Qin, Z., Derimian, Y., \& Karnieli, A. (2014). Derivation of land surface temperature for Landsat-8 TIRS using a split window algorithm. Sensors (Switzerland), 14(4), 5768-5780. https://doi.org/10.3390/s140405768

Sasky, P., Sobirin, \& Wibowo, A. (2017). Pengaruh Perubahan Penggunaan Tanah Terhadap Suhu Permukaan Daratan Metropolitan Bandung Raya Tahun 2000 - 2016. Industrial Research Workshop and National Seminar, 8(July), 354-361.

Sejati, A. E., Hasan, M., Nursalam, L. O., \& Harianto, E. (2020). Kesesuaian Pemetaan Penggunaan Lahan Permukiman Dengan Kondisi Sebenarnya Di Kecamatan Katobu Dan Kecamatan Duruka Kabupaten Muna. Jurnal Tunas Geografi, 09(01), 55-68.

Sekertekin, A., \& Bonafoni, S. (2020). Land surface temperature retrieval from Landsat 5, 7, and 8 over rural areas: Assessment of different retrieval algorithms and emissivity models and toolbox implementation. Remote Sensing, 12(2). https://doi.org/10.3390/rs12020294

Sugiyono. (2007). Stasitik Untuk Penelitian. Alfabeta.

Tan, K., Liao, Z., Du, P., \& Wu, L. (2017). Land surface temperature retrieval from Landsat 8 data and validation with geosensor network. Frontiers of Earth Science, 11(1), 20-34. https://doi.org/10.1007/s11707-0160570-7

Wang, L., Lu, Y., \& Yao, Y. (2019). Comparison of three algorithms for the retrieval of land surface temperature from Landsat 8 images. Sensors (Switzerland), 19(22). https://doi.org/10.3390/s19225049

Weng, Q., Firozjaei, M. K., Kiavarz, M., Alavipanah, S. K., \& Hamzeh, S. (2019). Normalizing land surface temperature for environmental parameters in mountainous and urban areas of a cold semi-arid climate. Science of the Total Environment, 650, 515-529.

https:// doi.org/10.1016/j.scitotenv.2 018.09.027

Wiweka, W. (2014). Pola Suhu Permukaan Dan Udara Menggunakan Citra Satelit Landsat Multitemporal. Jurnal Ecolab, $8(1)$, 11-22. https://doi.org/10.20886/jklh.2014.8. 1.11-22 